\title{
MARTIN C. PUTNA: Obrazy z kulturních dějin Střední Evropy [Scenes from the cultural history of Central Europe]
}

Praha: Vyšehrad, 2018. 378 s. ISBN 978-80-7429-977-3

DOI: https://doi.org/10.31577/WLS.2021.13.4.13

Martin C. Putna je známy literárny kritik, historik, prekladatel', rusista, teológ a komparatista, ktorý literatúru chápe $\mathrm{v}$ súvislostiach histórie, umenia, cirkevného vývinu a duchovných procesov $\mathrm{v}$ spoločnosti. Jeho diela zaujmú z hladiska lingvistiky, histórie umenia a literatúry, ale aj sociológie, politológie či religionistiky. Humorný a nadlahčený štýl, ktorý by nemusel vždy vyhoviet’ tzv. správnemu, ba ani tzv. zdravému spôsobu vyjadrovania, vnáša do jeho textov d’alšie dimenzie a nečakané prepojenia. Jeho práce akoby boli živou odpoved'ou na problémy, v ktorých sa zmietajú niektoré typy úvah $\mathrm{v}$ rôznych kultúrnych vrstvách súčasných spoločností. Putna sa však nevenuje iba súčasnosti, ale uvažuje aj o bezprostrednej minulosti. Vo svojich prednáškach a čítaniach $\mathrm{v}$ rozhlase, $\mathrm{v}$ periodikách a $\mathrm{v}$ rôznych laických či náboženských spolkoch sa okrem iného zaoberá aj nástupom marxizmu v západných kultúrach a jeho eschatologickou víziou dejín. $Z$ tohto hladiska rozobral aj otázku kolonializmu ako ohlas na politiku mocností podrobujúcich sa prudkej sebakritike, aby tým poukázal na rôznorodost' foriem a funkcií kolonialistických tendencií, ktoré sa na území strednej Európy prejavujú často v odlišných, protikladných a občas až nerozlíšitelných formách. Táto myšlienka sa $\mathrm{v}$ recenzovanej publikácii sformovala úplne spontánne, pretože jej ústredným problémom je stredná Európa a mýtus (niekedy až idylický) koloniálnej mocnosti Rakúsko-Uhorska $(280-281)$.

Kniha Obrazy z kulturních dějin Střední Evropy vyšla ako posledný zväzok trilógie kultúrnych dejín, zameranej najskôr na Západ (Obrazy z kulturních dějin americké religiozity, 2010), potom na Východ (Obra- zy z kulturních dějin ruské religiozity, 2015) a nakoniec na priestor medzi nimi, na stred. Putna si uvedomuje skutočnost', že predstavy o strednej Európe boli predmetom mnohých diskusií a prešli rôznymi zmenami. V ich rámci rozoznáva viacero typov podla toho, či vychádzajú z politického alebo kultúrneho delenia. Ako príklad prvého, politického typu konceptov strednej Európy uvádza tzv. „nemeckocentrické“, kde je priestor medzi Francúzskom a Ruskom vyplnený nemeckou civilizačnou misiou, alebo „federačné“, kam patrí koncept strednej Európy ako priestoru medzi Nemeckom a Sovietskym zväzom (Milan Hodža), ktorý vznikol po rozpade Rakúsko-Uhorska. Ako príklad druhého, kultúrneho typu delenia spomína tzv. „rakúskocentrické“, ale aj iné, ako podunajské alebo pol'skocentrické. On sám si zvolil odlišný prístup. Vychádza $\mathrm{z}$ hlibkových vhladov do kultúrnych dejín skúmaných oblastí, ich sociálneho a náboženského podložia, stratégie cirkví, ako aj národného cítenia, ktoré pomocou výrazových prostriedkov literárnych a umeleckých diel, názorov osobností alebo formovaním hnutí nadobúdajú formu určitých obrazov. Sú to vlastne slovné zobrazenia, takmer krátke príbehy historických osobností, ich diel alebo myšlienkových hnutí z obdobia prevažne 19 . storočia $\mathrm{z}$ rôznych regiónov rakúsko-uhorskej ríše. Tieto obrazy však nevyjadrujú dejinný, ale priestorový, občas takmer vizuálny charakter danej oblasti. Nie sú to ani predstavy aktérov z minulosti, ale videnie dnešného recipienta, ktoré vychádza $\mathrm{z}$ ich názorov a cielov, ale hodnotí ich dnes. Týmto spôsobom sa Putnovi podarilo zachytif život a kultúrne procesy v rámci Rakúsko-Uhorska zo širšieho a mimoriadne rozmanitého hladiska, pričom ča- 
sový či vývinový aspekt potlačil $\mathrm{v}$ prospech jazykových a umeleckých, no najmä geograficko-kultúrnych charakteristík určitého územia.

Pri podobne zložitej a premenlivej realite, akou žila stredná Európa v minulosti, nie je lahké nájst' konzistentné hladisko, ktoré by umožnilo vziat do úvahy všetky jej časti a podoby. Putnovi sa to podarilo tým, ako sám píše, že na rozdiel od predchádzajúcich dvoch dielov vychádzal $\mathrm{z}$ priestoru a nie $\mathrm{z}$ času. Niet pochýb, že $\mathrm{v}$ myslení strednej Európy je priestor dôležitým faktorom najmä preto, že mu chýba stabilita, pretože sa často mení a posúva. Priestor (vlastný, špecifický) utvára život istej kultúrnej komunity, ktorý dnes vnímame ako obraz miesta, jeho geografickej polohy, ludských aktivít a diel a súčasne ideových hnutí, do ktorých vstupujú aj konkrétne vlastnosti daného územia, napríklad nížin alebo hôr, často vyjadrené prostredníctvom symbolov alebo emblémov (strom, hory, rieky, živočíchy a pod.), ako to dokumentuje kultúrna geografia alebo antropológia. Výraz „obraz“ vysúva do popredia vzhlad priestoru, zachytáva však aj kultúrne a ideové reality. Toto vizuálne vnímanie reality sa osvedčilo ako mimoriadne vhodná pomôcka pri charakterizácii jednotlivých častí stredoeurópskych kultúr a ich premien. Vychádzajúc z komplexnej skutočnosti, ktorú „obraz“ strednej Európy či rakúsko-uhorskej ríše vyjadruje, rozdelil Putna predmet svojej práce na sedemnást' obrazov - kapitol, ktoré reprezentujú rôzne zemepisné oblasti strednej Európy, nachádzajúce sa bud' $\mathrm{v}$ rámci Rakúsko-Uhorska, presahujúce jeho hranice do iných štátnych celkov alebo vracajúce sa naspät. Výklad začína českým priestorom, čo je prirodzené, ale potom sa presúva k obrazu Moravy, dalej Sliezska, Horného a Dolného Rakúska, Štajerska, Korutánska, Salzburska, Tirolska, za ktorými nasleduje Slovinsko a Prímorie. V tomto momente sa pohlad obracia na druhú stranu, smerom $\mathrm{k}$ Uhorsku, kde výklad pokračuje obrazom Horného Uhorska a na druhej strane Sedmohradska. Nasleduje Chorvátsko a Dalmácia, ale vzápätí aj Halič, Bukovina a nakoniec Bosna. Už samotné poradie, akým Putna usporiadal svoj výklad jednotlivých území alebo obrazov, stojí za pozornost'. Ako sám píše, nevyberal ich náhodne, pretože kopírujú v zásade historické korunné územia habsburskej ríše približne $\mathrm{v}$ čase pred jej rozpadom. Ak si ich vizuálne predstavíme na rovnej ploche, vidíme pred sebou rozsiahle rozkúskované územie, ktoré siaha od severnej časti Európy na juh, až po Jadranské more. Ako sám autor píše, vychádzal $\mathrm{v}$ ňom zo zobrazení, ktoré našiel na starých turistických mapách bývalého mocnárstva. Samozrejme, tieto územia sa kryjú s rozdelením podla jazykov, národov a národností len čiastočne a sú grafickým znázornením skôr administratívnych a náboženských celkov ako národných entít. Preto je velmi užitočné, že každá zo sedemnástich častí práce začína mapou, velmi jednoduchou a názornou, ktorá jasne identifikuje dané územie. Autor sa odvoláva aj na práce iných autorov, napríklad na diela Claudia Magrisa a Karla-Markusa Gaussa, ale pripomína, že na rozdiel od nich mu dovolila jeho jazyková príprava v klasickej filológii, v slovanských a románskych jazykoch ponorit’ sa hlbšie do mnohojazyčného kultúrneho prostredia $\mathrm{v}$ oblasti Balkánu (a orientačne aj Mad’arska) a nezotrvávat' prevažne v rakúskom kultúrnom okruhu.

Kultúrne dianie na určitom území, v jednom alebo vo viacerých jazykoch, približuje autor prostredníctvom osobností a ich diel, významného titulu knihy či architektonickej pamiatky, náboženských spisov a vierovyznaní, pričom uvádza ich vzájomné súvislosti a podobnosti medzi nimi a charakterom území, ktoré sa oddelovali alebo pripájali. To znamená, že každá zo sedemnástich častí rakúsko-uhorského územia je samostatnou kapitolou, čiže obrazom diania vyčlenenej oblasti.

Pozrime sa teraz bližšie na niekol'ko vybraných prípadov. Putna tvrdí, že hladisko, z ktorého sa díva na strednú Európu, je české. Nielenže knihu začína obrazom českého priestoru, ale vyjadruje svoje poznanie českým jazykom. Český obraz, „Karel VI. Schwarzenberg a svatá koruna, Božena Něm- 
cová a svatá Babička“, predstavuje takmer model prístupu $\mathrm{k}$ dalším priestorom. $\mathrm{K}$ tomu pristupuje český jazyk, v ktorom Putna svoju prácu napísal. Je to prirodzené a súčasne jasnozrivé. Málokedy sa stretneme s takým jasným reflektovaním faktu, že obsah informácie je do velkej miery daný jazykom a jeho charakterom. V procese formulácie výpovede nehrajú úlohu len gramatické pravidlá jazyka, ale predovšetkým jeho vnútorná logika, ktorá (de)formuje každú správu (vedeckú, sociologickú, estetickú atd.) a posúva ju k odlišným významom. Je zrejmé, že Putna nemá na zreteli preklad, ale orientáciu na tie detaily, ktoré sa mu ako odchovancovi českej kultúry javia v priestore strednej Európy významnejšie. Môže to byt' napríklad obraz krajiny a územia, obývaného určitou kultúrnou skupinou (česká kotlina), dátum vzniku diel v národnom jazyku, spolužitie etník a národností s rôznym vierovyznaním, účast' a funkcia rôznych sociálnych vrstiev na budovaní národnej identity (národnost' ludová, vzdelanecká alebo aristokratická), konflikty týchto zložiek na určitom území a ich presahy do odlišných oblastí života. Západnú čast' strednej Európy, zemepisnú i kultúrnu blízkost’ $\mathrm{k}$ českému a moravskému priestoru napríklad reflektuje obrazom Dolného Rakúska a zviditelnuuje postavou Otta Weiningera a viedenskou vzburou proti biedermeieru. Otázka národnej identity dalej mohla byt' príčinou, prečo venoval pozornost' teórii slovanskej antiky, ktorú vytvorili slovinskí národovci v Kraňsku koncom 19. storočia (Davorin Martin Žunkovič) a ktorá hlásala nielen blízkost' Slovincov a Etruskov, ale aj predstavu Slovanov ako zakladatel'ov ultrapanslavistického celku na území Európy a ako praobyvatelov celej Európy. Tento názor si osvojil aj slovinský architekt Jože Plečnik, ktorý s ním prišiel do Prahy hladat špecifiku slovanského architektonického štýlu. Podobné prípady sú známe - nielen české Rukopisy zelenohorský a královédvorský či dielo Staroitalia slavjanská (Ján Kollár), ale aj lingvistické hypotézy, podla ktorých bol rumunský jazyk pôvodne jazykom celého Balkánu. Obrazu Slovenska sa venujú dve kapitoly - v rámci Uhorska ako takého, ktoré vystupuje ako územie nad jazykmi, a potom v rámci Karpatskej kotliny a Panónie. Z tohto kontextu vyrástla aj téma šlachtictva, $\mathrm{v}$ rámci ktorej má svoje miesto mad’arský spisovatel' Péter Esterházy. S ním sa ocitáme napríklad na (dnešnom) južnom Slovensku, kedže pôvodne zemiansky rod Esterházyovcov pochádza z Galanty, ale aj v Mad’arsku, kde spisovatel' prežil problémy 20. storočia, ktoré zasiahli celú stredovýchodnú čast’ Európy. V nasledujúcej kapitole sa Putna posunul len kúsok na sever, k Jurajovi Tranovskému a jeho barokovému evanjelickému kancionálu Tranoscius, a vzápätí na juh, do Budapešti k Jánovi Kollárovi. To, čo majú územia od severných hraníc Čiech, Moravy a Sliezska cez stredné Slovensko až k Dolnej zemi a k mnohonárodnostnému a multilingválnemu centru Budapešti spoločné, je nielen ich jazyková, etnická a náboženská diverzita, ale aj ich vnútorné prepojenia, dynamika kultúrnych i politických vztahov (národopisné výstavy, kongresy národností atd.). Putna spomína aj dalšie súvislosti, napríklad fenomén unitariánstva a uniatstva v mnohonárodnostnom a mnohojazyčnom priestore strednej Európy - v Sedmohradsku. Sedmohradsko ako súčast' Uhorska bolo obývané tromi štátnymi národmi s tromi jazykmi katolíckeho a reformovaného vierovyznania. Iba ten posledný, tolerovaný, rumunský národ si uchoval pravoslávnu cirkev. A práve tu vznikli dva zaujímavé javy - unitariánstvo ako pokus Sikulov dovŕšit celú európsku reformáciu, smerujúcu takmer k osvietenstvu (Ferenc Dávid, Kluž, 16. stor.), a uniatstvo ako spojenie pravoslávnej cirkvi a katolicizmu, ktoré umožnilo Rumunom dostat' sa $\mathrm{k}$ vzdelaniu $\mathrm{v}$ latinčine na seminároch vo Viedni a v Ríme a iniciovat osvietenské hnutie $\mathrm{v}$ celom Rumunsku vrátane Munténska a Moldavska. Z tohto prepojenia vyšiel rumunský klerik a osvietenec Ion Budai Deleanu (1760 - 1820), ktorý študoval vo Viedni a neskôr vo Lvove napísal heroikomický epos Țiganiada (Cikaniáda, čes. 1972) v rumunčine, čím rumunská literatúra vstúpila do európskej modernity. Nestalo sa tak náhodou. Práve vo Lvove bolo centrum uniatskej 
cirkvi v Haliči, ktorú tamojší spisovatel Taras Prochasko nazval cirkvou strednej Európy, pretože podla neho je stredová, medzi Východom a Západom. Od gréckokatolíckej moderny v Haliči potom Putna presúva svoj výklad do Bukoviny k židovskej moderne, Karlovi Emilovi Franzosovi, Paulovi Celanovi a Gregorovi von Rezzorimu. Mimoriadne zaujímavá je posledná čast venovaná Bosne, kde sa autor zaoberá vztahmi medzi európskym krestanstvom a prienikom osmanskej kultúry do strednej Európy a pokračuje až do súčasnosti, aby definoval jav nazvaný slovanský islam. Všetky spomínané javy, udalosti a osobnosti, často málo známe a zdanlivo bezvýznamné, sa takto stávajú súčastou nielen istého územia, ale spolutvorcami kultúrneho a intelektuálneho či politického diania na celom území strednej Európy. Pritom do tohto celku preniká na západe nemecký prvok, na juhu taliansky a turecký, na východe rusínsky a ruský a na severe pol'ský.

$\mathrm{V}$ závere knihy, nazvanom príznačne „Střední Evropa, most západní modernity“, Martin C. Putna načrtáva duchovné dejiny krajín a kultúr Rakúsko-Uhorska a zamýšla sa nad jeho významom pre strednú Európu. Sleduje kultúrne pohyby a dospieva $\mathrm{k}$ názoru, že Rakúsko-Uhorsko predstavovalo akýsi most, resp. trasu medzi západnou a východnou Európou (i ked' treba brat do úvahy aj opačný smer prieniku ideí). Rakúsko-Uhorsko malo v strednej Európe funkciu šíritela, pokračovatela, prenosu, ale nie tvorivosti. Tú vytvárali jej jednotlivé časti, každá $\mathrm{z}$ vlastných, ale aj spoločných a zmiešaných zdrojov. Je pochopitelné, že istá stredoeurópska nostalgia po Rakúsko-Uhorsku pretrváva i dnes. Výrazne však vystúpila do popredia $\mathrm{v}$ druhej polovici 20. storočia $\mathrm{v}$ čase upevnenia tzv. socialistického bloku, vyvolaného vojenským nátlakom z Východu. Ako $\mathrm{z}$ tohto hladiska hodnotit koloniálne ambície a praktiky bývalého Rakúsko-Uhorska? Túto otázku si Putna kladie s celou naliehavostou a odpovedá, že bezpochyby existovala určitá rakúska civilizačná misia, a to napriek útlaku a imperiálnemu násiliu, ktoré ju sprevádzalo. Potvrdzuje to množstvo aktivít $\mathrm{v}$ kultúre i spoločnosti tej doby. Kniha Martina C. Putnu vynáša na svetlo množstvo historických osobností, diel, udalostí či okolností, kultúrnych odkazov na reálie i názory a hnutia, ako aj mnohé zaujímavé detaily, ktoré sa koncentrujú v kultúrnom obraze strednej Európy. Ich výber, ako píse, by sa bol dal urobit aj inak. A je tiež zrejmé, že text knihy sa musel vel'mi skracovat'. Možno aj vdaka tomu pôsobí jeho práca nielen velmi podnetne, ale aj zaujímavo, zábavne a vzdušne. Ale čo je hlavné, text knihy v podstate vyjadruje radost z čítania, poznávania, $\mathrm{z}$ nájdených súvislostí a odhalených či neznámych okolností.

LIBUŠA VAJDOVÁ

Ústav svetovej literatúry SAV Slovenská republika 